\section{UK research centre programme gathers speed despite doubts}

\section{London}

Pruposals to set up a series of interdisciplinary research centres (IRCs) within Britain's higher education system continue apace despite a deep undercurrent of scepticism from many rank-and-file researchers. The government has given its seal of approval to the concept, which is being vigorously pursued by the four principal scientific research councils. The Advisory Board for the Research Councils (ABRC), which gives the government guidance on how the science budget should be divided, was due to meet earlier this week to consider draft proposals from each of the research councils for the next batch of centres. So far, four centres have been given the go-ahead, all under the auspices of the Science and Engineering Research Council (SERC). In its forthcoming public expenditure bid, the ABRC is expected to ask for sufficient extra cash to start about a dozen further centres.

The Agricultural and Food Research Council (AFRC) earlier this year invited institutions to bid to host centres from a list of eight possible areas of research. A shortlist of three priority areas has now been arrived at: animal transgenic biology, plant molecular biology and, with the Natural Environment Research Council (NERC) and the Economic and Social Research Council, agricultural environment and land use (the subject of a failed $£ 5.7$ million programme bid last autumn).

NERC will be seeking some $£ 20$ million to relocate the Institute of Oceanographic Sciences Deacon Laboratory in Surrey to the University of Southampton to create an IRC in deep-sea oceanography. Six more IRCs have been proposed, including, in common with SERC, one for atmospheric sciences (the bids are separate).

The Medical Research Council has been given approval to relocate its toxicology unit from Carshalton in Surrey to form an IRC at an as yet unspecified university site. The MRC has put in three further bids, for cell biology, in London; macromolecular engineering, probably at Cambridge; and therapeutic immunology, for which a location has yet to be agreed.

Since announcing its first four IRCs, SERC has received some 300 suggestions for further centres. Plans for a centre in novel semiconductor materials at Imperial College, London, are likely to get final approval in June. SERC's first centre, in superconductivity, based at Cambridge and announced in December, has yet to open. Discussions are continuing between the university, the University Grants Committee and SERC on financial and administrative details. The centre will be officially inaugurated on 21
June. Until the centre receives its money, a director cannot be appointed.

Despite the enthusiasm of the research councils, doubts about the wisdom of the IRC concept remain. The Association of University Teachers has expressed "grave concern" that the centres could "move all too readily towards establishment as private autonomous institutions", undermining the quality of teaching at the host institutions. The other chief concern is that the centres represent an unhealthy move towards too much directed research with little room for creativity and innovation.

Worries also persist about the speed with which the programme is moving when fine details on such aspects as the centres' management apparently remain to be resolved. It was only last July that the idea for IRCs received a full airing, when the ABRC published its now

\section{Bonn}

AnNual budget squabbles notwithstanding, West German Research Minister Heinz Riesenhuber takes much of the credit that support for basic research in West Germany has increased steadily during his six-year tenure of office. The percentage of the Ministry's budget devoted to basic research has increased from 26 to 39 per cent during that stretch.

Riesenhuber now says he is trying this year to give basic research a European dimension. As president for six months of the European Community (EC) Council of Science Ministers, he is concentrating on defining European participation in the Japanese Human Frontiers Science Program and on uniformity bioethical standards in the European Communities.

Just days before the next international conference on Human Frontiers, Riesenhuber reduced the possible goals of the still-nebulous programme by one. Sequencing the human genome would be "too technocratic" for Human Frontiers, he says.

Within Europe, concern is growing about the implications of the big step towards integration planned for 1992, when the twelve member countries have to agree on norms in education and production. Riesenhuber had comforting words for West German researchers, saying there would be "no caesura" for them in 1992. Scientific exchange is already quite successful between West Germany and smaller European states, although notorious discussion document, $A$ Strategy for the Science Base (see Nature $328,280 ; 1987)$. One factor in the equation that $A B R C$ had envisaged, but which has been overtaken by the speed of events, is the role of the new Centre for Exploitation of Science and Technology (CEST). Launched last November and financed mainly by private industry (see Nature 330, 196; 1987), CEST has yet to move into permanent premises and recruit its full complement of ten staff. It has not been involved in selecting the present list of IRCs being considered by the ABRC. Chief executive Bob Whelan is nevertheless confident the CEST will have a central role to play in the selection of topics of importance for future IRCs. Whelan said this week that CEST would aim to develop a close relationship with the individual research councils. He also injected a note of caution into the process of deciding which topics to pursue. "I want to avoid snap judgements - - selection of areas has to be based on robust data, well-argued and logical." Simon Hadlington

\title{
Minister champions European cause for West German research
}

Riesenhuber believes that exchange with France and Great Britain could be improved.

Riesenhuber's remedy is not only to concentrate university studies on the essentials, but also to reduce the number of school years from thirteen to twelve. (Such a proposal seems unlikely to gain acceptance in all of West Germany, though individual Länder may accept it.) In a recent speech, Riesenhuber disputed claims that 25-year-old university graduates left to do their own research might be 'irreverent'. "Irreverence in thinking is of significant value to science", he said.

Riesenhuber admits that arriving at European agreements on ethical matters such as research on human embryos or manipulation of the human germ line would be "extraordinarily difficult", but claims the situation is "not hopeless". In Riesenhuber's view, it is tolerable that European states should differ on complex matters as long as there is agreement on fundamental ethical questions.

Although he does not expect a unified set of European norms for such research in the EC, Riesenhuber said it is desirable that the various points of view "approach each other" as a result of public discussion involving researchers in the natural sciences, philosophy, theology and the law. "Parallel political decisions will only be possible" if such experts can arrive at some sort of consensus in advance. Experience in West Germany shows that the groups have not differed nearly as much as was expected. 